\title{
THE INFLUENCES OF REGIONAL CREDIT GUARANTEE (JAMKRIDA), WORKING CAPITAL, AND GOVERNMENT'S ROLE ON MICRO, SMALL AND MEDIUM ENTERPRISES (MSMES) WELFARE IN DENPASAR CITY
}

\author{
Ni G.A.N. Adyani Utari, Made Kembar Sri Budhi \\ Faculty of Economics and Business, University of Udayana, Bali, Indonesia \\ *E-mail: gex sree@yahoo.com
}

\begin{abstract}
The Micro Small and Medium Enterprises (MSMEs) in Denpasar city faced a various obstacles in developing their business such as limited access to capital or collateral despite having a feasible business, limited working capital conditions and lack of government's role in order to encourage the development of MSMEs. This study aims to analyze the effect of regional credit guarantee, working capital and government's role on income and welfare of Denpasar's MSMEs and welfare of Denpasar's MSMEs through income. The research use Partial Least Square (PLS) approach analysis. The study was conducted on Denpasar city by examining 87 samples from 652 populations. Determination of sample with stratified random sampling. The results of the analysis show that regional credit guarantee, working capital and government's role significantly affect income of Denpasar's MSMEs. Regional credit guarantee, working capital and income affect welfare of Denpasar's MSMEs while government's role has no significant effect on welfare of Denpasar's MSMEs. Regional credit guarantee, working capital and government's role have an indirect effect on welfare of Denpasar's MSMEs through income.
\end{abstract}

\section{KEY WORDS}

MSMEs, regional credit guarantee, working capital, government's role, income, welfare.

The Micro, Small and Medium Enterprises (MSMEs) plays an important role in the strategic role of economic development (Kerry, 2010). Contributions given by MSMEs in economic crisis conditions are considered as a support in the process of national economic recovery, seen from the national economic growth rate and in increasing employment opportunities (Putra, 2013). MSMEs contribute significantly, thus increasing foreign exchange for the country, making this sector emerge as a very strong pillar both in terms of income and in terms of labor (Subramanian, 2012). The development of MSMEs is important to reflect on the condition of MSMEs that are able to survive in times of crisis (Supriyanto, 2006). Therefore, in the development of a strong people's economy, the development of small industries and households is one of the priorities.

Even though MSMEs have a very potential position in the economy, in reality there are still many problems faced. The problems of almost all MSMEs that cannot develop compared to large businesses include lack of capital they have, limited access to funding and the lack of optimal role of the government. The classic and fundamental problem faced by MSMEs is capital. Working capital in a business has a very important role on supporting business activities. Working capital is needed to finance daily operational activities. Expected working capital is expected to be able to return to the company in a short period of time through the sale of production. Working capital originating from product sales will soon be issued again to finance further operational activities. Every business tries to sufficient its working capital needs to increase liquidity and maximize revenue (Kasmir, 2008).

The role of the government is needed by implementing the empowerment of MSMEs so that MSMEs become strong, independent and can develop. Strengthening capital, regional credit guarantee and empowerment of MSMEs implemented by the government have a positive effect on the development of MSMEs, which is reflected in the increase in income, turnover and profits which will have an impact on improving the welfare of MSMEs. This is in line with the research conducted by Inayah, et al (2014), concluding that working 
capital loans have a positive effect on the net income of the formal and small-scale businesses. The more working capital loans obtained, the more income that will be obtained by MSMEs. Working capital loans will increase the capital owned by MSMEs, the capital can be used to improve the production process of goods and pay labor wages. With additional capital provided for MSMEs, the income earned will increase, because it can produce goods and absorb more labor. Income levels are often used by economists as a measure of welfare (Supartono et al., 2011).

To find out the level of welfare of MSME actors can be measured by health, economic conditions, happiness and quality of life of the people (Widyastuti, 2012). The success of MSME actors in achieving their goals can be measured by improving their welfare. Social welfare is a nation's system of benefits and services to help the community to obtain social, economic, educational and health needs that are important for the survival of society (Whithaker and Federico in Sasana 2009).

This study aims to analyze the effect of regional credit guarantees, working capital and the role of the government on MSME income, analyze the influence of regional credit guarantees, working capital, the role of government and income to the welfare of MSME actors and analyze the indirect effects of regional credit guarantees, working capital and government roles towards the welfare of SMEs in Denpasar City through income variables. The conceptual framework that describes the relationship between variables in this study, can be seen in Figure 1.

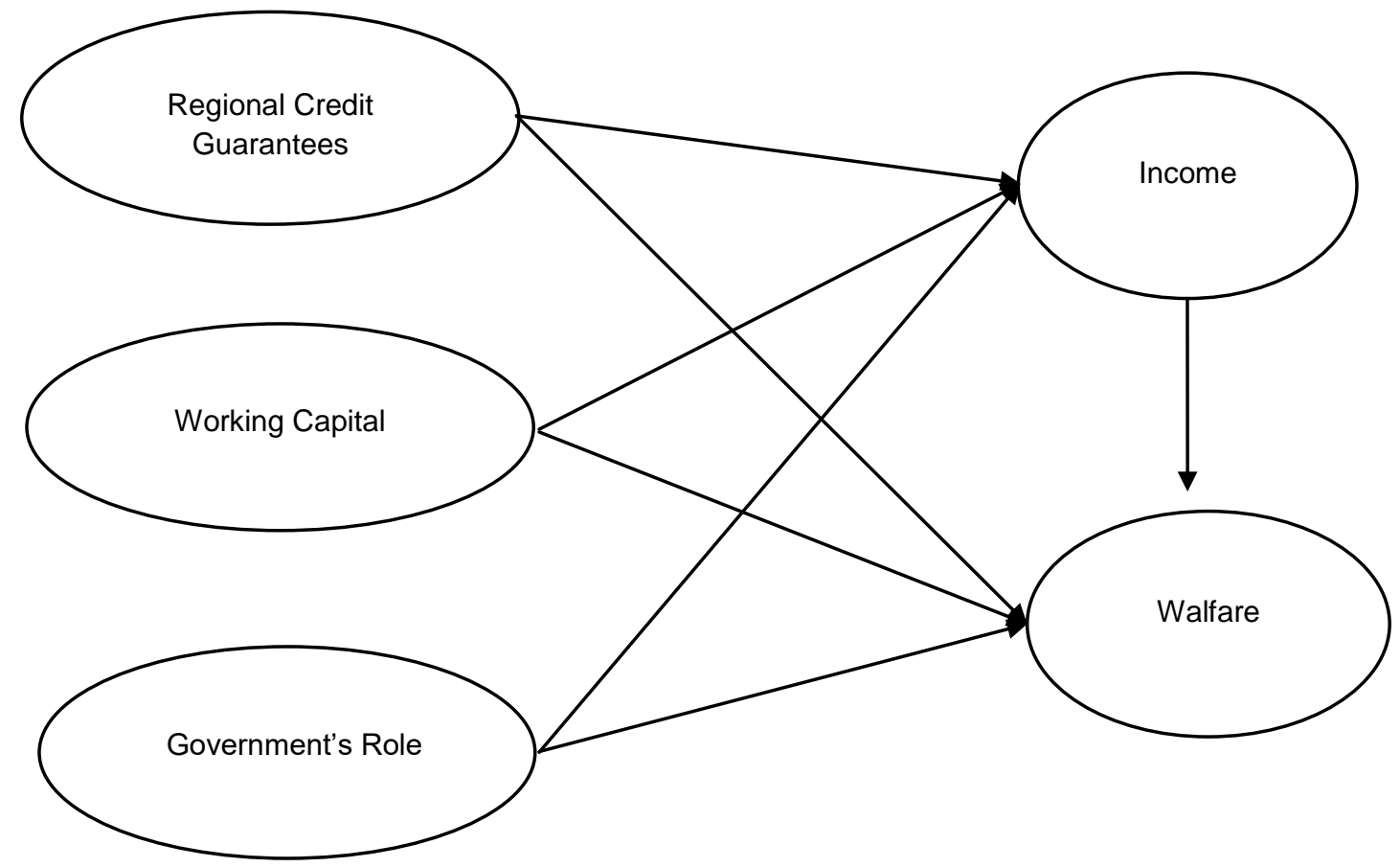

Figure 1 - Conceptual Framework

\section{METHODS OF RESEARCH}

This research was conducted in Denpasar City. The reason for choosing this location is that based on existing data, Denpasar City has the most number of MSMEs and uses or obtains credit through the guarantee of PT Jamkrida Bali Mandara at most. The sample was taken as many as 87 respondents from 652 people population. The sample determination method uses the stratified random sampling method. After calculating the sample from each strata, the sample is randomly determined through a computer. 
Table 1 - Number of Samples in Each Category or Type of Procurement

\begin{tabular}{ccc}
\hline No & Category & Number of Samples \\
\hline 1 & Trade & 78 \\
2 & Construction & 5 \\
3 & Service & 3 \\
4 & Agriculture & 1 \\
\hline & Total & 87 \\
\hline
\end{tabular}

Source: PT. Jamkrida Bali Mandara, 2017

The basic form used in this questionnaire is close ended questions and scaled response questions. The data analysis technique used to determine the effect of the variables observed in this study, namely the influence of community participation is the Partial Least Square (PLS) technique. The research variables used are Income $\left(Y_{1}\right)$, Walfare $\left(\mathrm{Y}_{2}\right)$, Regional Credit Guarantee $\left(\mathrm{X}_{1}\right)$, Working Capital $\left(\mathrm{X}_{2}\right)$, and Government"s Role $\left(\mathrm{X}_{3}\right)$.

Structural models (Inner Model) of Endogenous latent variables of income as follows.

$\eta 1=\gamma 1 \varepsilon 1+\gamma 2 \varepsilon 2+\gamma 3 \varepsilon 3+\varsigma 1$

Where: $\eta 1$ - Endogenous Variable Income; $\gamma 1$ - The coefficient of influence of exogenous variables Credit Guarantee; $\gamma 2$ - Coefficient of influence of exogenous variables Working Capital; $>3$ - Coefficient of influence of exogenous variables Community Role; $\varsigma 1$ - Model error.

Structural models (Inner Model) of Endogenous latent variables of walfare as follows.

$\eta 2=\beta 1 \eta 1+\gamma 6 \varepsilon 1+\gamma 7 \varepsilon 2+\gamma 8 \varepsilon 3+\gamma 9 \varepsilon 3+\gamma 10 \varepsilon 3+\varsigma 2$

Where: $\eta 2$ - Endogenous variables of well-being; $\beta 1$ - The coefficient of influence of endogenous variable income; $\gamma 6$ - The coefficient of influence of exogenous credit guarantee variables; $\gamma 7$ - The coefficient of influence of exogenous variables on working capital; $\gamma 8$ The coefficient of influence of exogenous variables on the role of government; $\$ 2$ - Model error.

Measurement Model (Outer Model) of Latent Variable of Credit Guarantee:

$$
\begin{aligned}
& \mathrm{X} 1.1=\lambda \mathrm{X} 1 \mathrm{PM}+\delta 1 \\
& \mathrm{X} 1.2=\lambda \mathrm{X} 2 \mathrm{PM}+\delta 2 \\
& \mathrm{X} 1.3=\lambda \mathrm{XPM}+\delta 3
\end{aligned}
$$

Latent Variable of Working Capital:

$$
\begin{aligned}
& \text { X2.1 }=\lambda \text { X4KS }+\delta 5 \\
& \text { X2.2 }=\lambda \text { X5KS }+\delta 6 \\
& \text { X2.3 }=\lambda \text { X6KS }+\delta 7
\end{aligned}
$$

Latent Variable of Government Role:

$$
\begin{aligned}
& X 3.1=\lambda X 7 K S+\delta 8 \\
& X 3.2=\lambda X 8 K S+\delta 9 \\
& X 3.3=\lambda X 9 K S+\delta 10
\end{aligned}
$$

Latent Variable of Income:

$$
\begin{aligned}
& \mathrm{Y} 1.1=\lambda \mathrm{Y} 1 \mathrm{EE}+\epsilon 1 \\
& \mathrm{Y} 1.2=\lambda \mathrm{Y} 2 \mathrm{EE}+\epsilon 2 \\
& \mathrm{Y} 1.3=\lambda \mathrm{YEE}+\epsilon 3
\end{aligned}
$$


Latent Variable of Walfare:

$$
\begin{aligned}
& \mathrm{Y} 2.1=\lambda \mathrm{Y} 5 \mathrm{EE}+\epsilon 10 \\
& \mathrm{Y} 2.2=\lambda \mathrm{Y} 6 \mathrm{EE}+\epsilon 11 \\
& \mathrm{Y} 2.3=\lambda \mathrm{Y} 7 \mathrm{EE}+\epsilon 12
\end{aligned}
$$

\section{RESULTS AND DISCUSSION}

Based on the results of the analysis of total influence testing as presented in the Table 2 , it shows that regional credit guarantees, working capital and government roles have a significant positive effect on welfare and regional credit guarantees, working capital and

\begin{tabular}{|c|c|c|c|c|c|}
\hline Relationship & Original Sample (O) & Sample Mean (M) & Standard Error (Sterr) & T Statistic (O)/Stere) & $P$ Values \\
\hline $\mathrm{PKD}(\mathrm{X} 1) \rightarrow \mathrm{PDP}(\mathrm{Y} 1)$ & 0,324 & 0,329 & 0,086 & 3,743 & 0,000 \\
\hline $\mathrm{PKD}(\mathrm{X} 1) \rightarrow \mathrm{KSJ}(\mathrm{Y} 2)$ & 0.386 & 0,354 & 0,092 & 3,872 & 0,000 \\
\hline $\mathrm{MK}(\mathrm{X} 2) \rightarrow \mathrm{PDP}(\mathrm{Y} 1)$ & 0,249 & 0,247 & 0,090 & 2,771 & 0,003 \\
\hline $\mathrm{MK}(\mathrm{X} 2) \rightarrow \mathrm{KSJ}(\mathrm{Y} 2)$ & 0,319 & 0,323 & 0,100 & 3,206 & 0,003 \\
\hline $\mathrm{PP}(\mathrm{X} 3) \rightarrow \mathrm{PDP}(\mathrm{Y} 1)$ & 0,335 & 0,337 & 0,078 & 4,305 & 0,000 \\
\hline $\mathrm{PP}(\mathrm{X} 3) \rightarrow \mathrm{KSJ}(\mathrm{Y} 2)$ & 0,242 & 0,245 & 0,096 & 2,535 & 0,001 \\
\hline $\mathrm{PDP}\left(\mathrm{Y}_{1}\right) \rightarrow \mathrm{KSJ}\left(\mathrm{Y}_{2}\right)$ & 0,340 & 0,334 & 0,087 & 3,930 & 0,000 \\
\hline
\end{tabular}
government roles have a significant positive effect on income.

Table 2 - Effect of Total / Total Effect of Research Variables

Source: Data processed, 2018.

Based on the results of the analysis using SmartPLS Version 3.00 the role of the government variable does not have a significant direct effect on the income variable, seen from the t-statistic value of 1,270 , which is smaller than 1.65 and $p$ value 0.102 , greater than the error used 0.1 . The income variable is significantly positive for the welfare variable. This means that the greater the income generated, the higher the welfare of MSME actors, and vice versa the smaller the income generated, the lower the welfare of MSME actors.

Regional credit guarantee, working capital and government roles have significant indirect effects on welfare variables through income, which means that the greater regional credit guarantees, working capital and the role of government, the higher the welfare received by MSME actors, and vice versa the smaller the regional credit guarantee received, the lower the welfare received by MSME.

With additional capital provided for MSMEs, the income earned will increase, because it can produce goods and absorb more labor. Besides that, the results of this study also support the theory of Kasmir (2011) which states that credit can positively increase income because credit can increase business capital.

The interview conducted with Ni Luh Gede Meigaratna Sari, MSME perpetrators on May 20, 2018 in Denpasar said:

'I am very grateful to be able to get credit with guarantee assistance from PT. Jamkrida Bali to develop my business in the field of fashion, namely traditional Balinese clothing. The loan is used to buy Balinese kebaya products which currently have creative and varied models and designs. Bali kebaya fabric is quite good prospect because it is always used for prayers and various traditional ceremonies in Bali. So there are always buyers. If a lot of buyers definitely add to our income'.

I Made Gede Dharmendra on May 27, 2018 in Denpasar said:

'Credit that I get is used to increase capital in the building material store that I manage. The capital is used to buy building materials or materials and then sell again. This business needs big capital but is profitable because people who build don't know the season so they can build and quite fortunately anytime'.

The results of interviews with providers show that credit guarantees obtained affect business development. With additional capital, MSME actors can attract greater business opportunities such as buying production equipment, buying raw materials or buying items to be resold. Increased production activities will affect the increase in income of MSME players. 
The interview conducted with Gde Budi Dwipayana, Head of Guarantee for PT Jamkrida Bali on May 23, 2018 in Denpasar said:

'As a regional guarantee institution, we want to provide the maximum benefit to the community, but guarantee activities especially for productive business activities have a higher risk than non-productive so we have to be more prudent. We want to provide as much access as possible to MSMEs but remain cautious in providing guarantees. Don't let PT. Jamkrida, which must solve problems, creates new problems because many debtors are defaulted. Usually in terms of socialization, we do not run into socialization to the mass media but usually to places where most people have productive businesses that are worthy of being guaranteed'.

The interview results show that PT. Jamkrida Bali strongly supports the flexibility of access for MSME players in obtaining business capital. Various efforts have been carried out such as having a very strategic office in the center of Denpasar City, the breadth of a network of cooperation with banks or non-bank institutions in all districts / cities throughout Bali, as well as continuous and sustainable socialization to the regions. Good access will increase public interest in obtaining credit guarantees through PT. Jamkrida. But in this effort, PT. Jamkrida also applies the aspect of prudence in providing credit guarantees in accordance with applicable regulations. It is also evident in the outreach approach that was carried out not through communication media to disseminate information but directly targeting places that were potentially good for channeling guarantees.

The working capital variable measured here has indicators including cash turnover, inventory turnover and account receivable turnover. This is due to sufficient working capital that can be used to meet all operational needs in business, such as buying raw materials, employee salaries, retail goods, etc. that can increase business productivity and produce maximum profits so that it can be distributed to achieve the standard of living feasibility perceived by the public.

The Regional Government is required to provide better service and empower the community so that the standard of living of the people is guaranteed and certainly can improve the welfare and progress of the region (Sadid 2012). In improving the welfare of rural communities, the Village Government must be made aware of and cared for. The results of the analysis of this study indicate that the role of the government does not significantly affect the welfare of MSME actors in Denpasar City.

Many government policies have directly touched MSMEs such as the People's Business Credit (KUR) distribution program, where KUR funds channeled to the public are increasing year by year. Efforts are being made to boost KUR distribution in 2018 by reducing interest rates from $9 \%$ to $7 \%$. In addition to lowering credit interest, the government also decided to increase the KUR distribution portion for the production sector by $50 \%$ of the total KUR target of 120 trillion. From the results of the study, most MSMEs in Denpasar City already knew about the KUR program through various socialization activities carried out by the Central Government, Regional Governments and KUR channeling banks.

The programs initiated by the Government have varied for alignments to MSMEs but have not been sufficiently integrated so that they have not provided optimal results. More intensive coordination and collaboration between government agencies in the whole process from planning, budgeting, implementation to monitoring and evaluation related to MSMEs are needed. It is hoped that the Government will not be trapped in sectoral egos, organizational egos or their respective ego programs. Because basically all the problems in the community are cross-sectoral and even cross-regional. On the other hand, in addition to the government's role, it takes an active role for banks and State-owned enterprises or regional owned enterprises to facilitate coaching, banking access, and other activities.

Besides that, the programs that are lack of attention are followed up on throughout the process. Government apparatus should emphasize the follow-up of the results of monitoring and evaluation or coaching so that it can be clearly known the inequality, inefficiency, and ineffectiveness on carrying out operational activities. Follow-up is an improvement activity for the program that is carried out so that in the future the program implemented can be implemented even better. 
Furthermore, the MSMEs of Denpasar City can develop and be highly competitive so as to produce reliable MSMEs in global competition, it is necessary to have innovative, sustainable and inclusive policies and programs. Economic growth should be felt by all levels, so it is important to make new initiatives to reduce the welfare range in Denpasar City.

Segel and Bruzy in Widyastuti (2012), also explained that welfare can be measured by health, economic conditions, happiness and quality of life of the people. The middle-class community welfare can be represented by the level of life of the community which is characterized by the absence of poverty, a better level of health, higher levels of education and productivity of the community (Todaro, 2000). The relationship between income and welfare of members is if economic growth or income is good then the level of community welfare will also increase.

\section{CONCLUSSION AND RECOMMENDATIONS}

The higher the regional credit guarantee obtained and the higher the working capital owned, the higher the income earned. While the government's role negatively affects the income of SMEs in Denpasar City. The higher the regional credit guarantee obtained, the higher the working capital owned, the greater the role of the government carried out and the higher the income obtained, the higher the welfare obtained. Regional credit guarantees, working capital and the government's role indirectly influence income through the welfare of MSME actors in Denpasar City.

Government should be more active in providing guidance to MSMEs to improve their human resource capabilities by conducting training, workshops, and technical guidance that is in line with the needs of MSMEs. The development of MSMEs can be carried out in synergy with the regional apparatus in the Regional Government, cooperating with State Owned Enterprise of Indonesia, private institution, and university. The government should give priority in developing MSMEs by providing clear planning, budgeting and human resources placement so that intensive guidance can be carried out thoroughly and given the importance of MSMEs in increasing regional economy. With guidance it is hoped that MSMEs will not run stagnant but rise in class and have high competitiveness. Besides that, guidance from the Government is also to encourage the growth of new MSMEs. Whereas for MSME, it is suggested that increasing participation in term of government program to support MSMEs development.

This study has several limitations, namely in this study the object of research is the MSMEs of Denpasar City who received a guarantee program from PT. Jamkrida Bali, so that it has not accommodated the perceptions of SMEs throughout Bali. There are still many variables that can affect the income and welfare of MSME actors. Future research is expected to increase the number of research variables used.

\section{REFERENCES}

1. Agnes, Sawir. 2015. Analisis Kinerja Keuangan dan Perencanaan Keuangan Perusahaan. Jakarta: Agung Media.

2. Amanaturrohim, Hanifah. 2015. Pengaruh Pendapatan dan Konsumsi Rumah Tangga terhadap Kesejahteraan Keluarga Petani Penggarap Kopi di Kecamatan Candiroto Kabupaten Temanggung. Universitas Negeri Semarang.

3. Ana, Suwendra, dkk. 2014. Pengaruh Pemberian Kredit dan Modal Terhadap Pendapatan UKM. E-Journal Bisma Universitas Pendidikan Ganesha Jurusan Manajemen. Vol 2.

4. Arthur J. Keown, David F. Scott, Jr., John D. Martin, J. William Petty. 2000. Dasar-Dasar Manajemen Keuangan, Edisi Satu, Penerbit Salemba Empat, Jakarta.

5. Denis, Prasetya Budi. 2014. Peranan Kredit Usaha Dalam Mewujudkan Kesejahteraan Sosial Ekonomi Pedagang di Sentra Bisnis Driyorejo. Universitas Negeri Surabaya Jurusan Pendidikan Ekonomi. Fakultas Ekonomi. 
6. Djumhana, Muhammad. 2000. Hukum Perbankan di Indonesia. Bandung. PT. Citra Aditya Bakti.

7. Etzioni, Amitai. 1999. The Limits of Privacy. (New York: Basic Books, 1999).

8. Fuad M. 2002. Pengantar Bisnis. Jakarta. PT. Gramedia Pustaka Utama.

9. Gregory, Paul R and Robert C Stuart, Competitive Economic System Edisi ke-4. Boston. Houghton Miffin Company. 1981.

10. Hafidoh. 2015. Pengaruh Pemanfaatan Dana Zakat Produktif Terhadap Tingkat Penghasilan Mustahik di Pos Keadilan Peduli Ummat (PKPU) Yogyakarta. Skripsi. Universitas Islam Negri Sunan Kalijaga Yogyakarta.

11. Hartati, Radi. 2017. Analisis Faktor-faktor yang Mempengaruhi Kesejahteraan Petani di Kota Denpasar. E-journal Ekonomi dan Bisnis Universitas Udayana 6.4 (2017).

12. Hasibuan, Malayu. 2001. Dasar-dasar Perbankan. Jakarta: Bumi Aksara

13. Hendrik. 2011. Analisis Pendapatan dan Tingkat Kesejahteraan Masyarakat Nelayan Danau Pulau Besar dan Danau Bawah di Kecamatan Dayun Kabupaten Siak Provinsi Riau. Dalam Jurnal Perikanan dan Kelautan, volume 16 No. 1. Hal 21-32 Riau: Universitas Riau.

14. Ikatan Akutansi Indonesia. 2004. Standar Akutansi Keuangan. Jakarta. Salemba Empat.

15. Ikatan Akutansi Indonesia. 2004. Standar Akutansi Keuangan. Jakarta. Salemba Empat.

16. Inayah, Nurul, dkk. 2014. Pengaruh Kredit Modal Kerja Terhadap Pendapatan Bersih Usaha Kecil dan Menengah (UKM) Sektor Formal. E-Journal Bisma Universitas Pendidikan Ganesha Jurusan Manajemen. Vol 2.

17. Irianto, Heru. 2005. Strategi Pemberdayaan UMKMdi Wilayah Surakarta. Makalah ini disampaikan dalam diskusi regional Kerjasama Bank Indonesia Solo dengan Badan Koordinasi Pembangunan Lintas Kabupaten/Kota Wilayah II Surakarta Provinsi Jawa Tengah. Solo 30 Juni 2005.

18. Kasmir, 2008. Analisis Laporan Keuangan. Cetakan Kedelapan. Jakarta. PT. Raja Grafindo Persada.

19. Kasmir, 2010. Pengantar Manajemen Keuangan. Edisi I. Cetakan Kedua. Jakarta. Kencana.

20. Keputusan Menteri Keuangan Republik Indonesia Nomor 486/KMK.017/1996. 1996. Perusahaan Penjaminan.

21. Kerry, S.M. 2010. Problem and Prospect of SMEs Loan Management: A study on Merchantile Bank Limited, Khulna Branch. Journal of Business and Technology (Dhaka), $\mathrm{V}(2)$, pp: 38-52.

22. Khoirun Nisak. 2012. Pengaruh Pinjaman Modal Terhadap Pendapatan Usaha Mikro, Kecil dan Menengah di Kota Mojokerto

23. Komaruddin Sastradipoera. 2004. Strategi manajemen Bisnis Perbankan. Bandung. Kappa Sigma.

24. Kuncoro, Mudrajad. 2004. Ekonomi dan Pembangunan Daerah. UGM.

25. Labolo, Muhadam, 2010. Memahami Ilmu Pemerintahan Suatu Kajian, teori, Konsep, dan Pengembangannya. Jakarta: Rajawali Pers.

26. Mulyono, T. 1987. Manajemen Perkreditan Komersil. BPFE. Yogyakarta.

27. Munizu, M. 2010. Pengaruh faktor-faktor eksternal dan Internal Terhadap Kinerja Usaha Mikro dan Kecil (UMK) di Sulawesi Selatan. Jurnal Manajemen dan Kewirausahaan, 12 (I), hal: 33-41.

28. Nazir, Moh. 2005. Metode Penelitian. Ghalia Indonesia. Bogor.

29. Partomo, Soedjono. 2004. Ekonomi Skala Kecil/Menengah dan Koperasi. Ghalia Indonesia. Bogor.

30. Peraturan Presiden Nomor 2. 2008. Lembaga Penjaminan.

31. Pitma Pertiwi. 2015. Analisis Faktor-Faktor Yang Mempengaruhi Pendapatan Tenaga Kerja di Daerah Istimewah Yogyakarta. Skripsi. Universitas Negeri Yogyakarta

32. Putra, I Gusti Agung Alit Semara. 2013. Efektivitas dan Dampak Program Bantuan Kredit Usaha Rakyat (KUR) Terhadap Pendapatan dan Kesempatan Kerja UMKM di Kota Denpasar. E-Journal Ekonomi Pembangunan Universitas Udayana, 2 (10), hal: 457-468. 
33. R. Tjiptoadinugroho. 1990. Perbankan Masalah Perkreditan. Jakarta. PT. Prasdinya Paramita. Jakarta.

34. S. Munawir. 2004. Analisis Laporan Keuangan. Edisi Ke-4.Liberty. Yogyakarta.

35. Sadid Parassa, Helni. 2012. Peranan Pemerintah Dalam Peningkatan Kesejahteraan Masyarakat Desa Wasuponda Kabupaten Luwu Timur. Universitas Hasanudin. Sulawesi Selatan..

36. Sasana, H., 2009, “Analisis Dampak Pertumbuhan Ekonomi, Kesenjangan Antar Daerah dan Tenaga Kerja Terserap Terhadap Kesejahteraan di Kabupaten/Kota Provinsi Jawa Tengah Dalam Era Desentralisasi Fiskal", Jurnal Bisnis dan Ekonomi (JBE), Vol 16, Hal $1-50$.

37. Satrio, J. 1996. Hukum Jaminan Hak-Hak Jaminan Kebendaan. Bandung. Citra Aditya Bakti.

38. Subramanian, G. Vairava. 2012. Implementation of Credit Rating for SMEs-How is Beneficial to Indian SMEs? International Journal of Scientific and Research Publications, 2 (4), pp: 1-7.

39. Sugiono. 2014. Metode Penelitian Bisnis. Bandung: Alfabeta.

40. Sumanto, Agus. 2016. Pengaruh Kredit Investasi dan Kredit Modal Kerja Terhadap Kesejahteraan Masyarakat Kabupaten/Kota di Jawa Timur. JESP. Vol 8.

41. Supriyanto. 2006. Pemberdayaan UMKM Sebagai Salah Satu Upaya Penanggulangan Kemiskinan. Jurnal Ekonomi dan Pendidikan, 3 (I), hal: 1-16.

42. Swasono, 2005. Indonesia dan Doktrin Kesejahteraan Sosial, Perkumpulan Pra Karsa, Jakarta April 2005.

43. Swastha Basu. 2001. Manajemen Pemasaran I Edisi Ketiga. BPFE. Jakarta.

44. Todaro Michael. 2000. Pembangunan Ekonomi Dunia Ketiga, Edisi 7. Jakarta: Erlangga.

45. Tohar. 2000. Membuka Usaha Kecil. Penerbit Kanisius. Yogyakarta.

46. Undang-Undang Nomor 10. 1998. Perbankan.

47. Undang-Undang Nomor 20. 2008. Usaha Mikro, Kecil dan Menengah.

48. Veithzal Rivai. 2004. Manajemen Sumber Daya Manusia Untuk Perusahaan. Cetakan Pertama. Jakarta. PT. Raja Grafindo Persada.

49. Wiksuana, Bagus, Wiagustini, Panji Sedana. 2001. Buku Ajar Manajemen Keuangan. UPT Penerbit Universitas Udayana.

50. Widyastuti, Astriana. 2012. "Analisis Hubungan Antara Produktivitas Pekerja dan Tingkat Pendidikan Pekerja Terhadap Kesejahteraan Keluarga di Jawa Tengah Tahun 2009”, Economics Development Analysis Journal (EDAJ), Vol 2.

51. Wolfgang Friedmann. 1967. Legal Theory. Stevens \& Sons. London.

52. Yasin. 2010. Jurnal Pendidikan Ekonomi Vol.3. 